\title{
EVALUATION OF PLEXONAL * AS A PREOPERATIVE HYPNOTIC ${ }^{\dagger}$
}

\section{Gordon M. Wyant, f f a r a s., Anthony P Melgrave, M, B., B.S., * * Allen B. Dobkin, M D , and Christopher J. Kilduff, M.B., B.Ch.}

THE sucCEss of an operative procedure clepends upon many factors. It begins with the preoperative preparation of the patient and is not complete until the patient has recovered to the maximum degree possible from the condition fol which he was admitted to hospital. One of the many steps involved is to provide satisfactory sleep for the patient during the night preceding operation so that he may arrive in the operating room in a rested state The patient who is worn out by a restless night of tossing and turning and of worlying about the impending ordeal may be physically and mentally exhausted despite preoperative medication This exhaustion will have repercussions upon the whole progress of his recovery. In an attempt to provide this sleep, we are constantly searchıng among new drugs to find one which is predictable, non-toxic, non-depressing and which will leave no hangover

Plexonal is a new agent and it has been studied with these requirements in mind.

\section{Composition of Plexonal and Review of Literature}

Plexonal is a combination of five drugs and has the following formula

Sodium diethyl barbiturate (Barbital ${ }^{\circledR}$ ), $45 \mathrm{mg}$

Sodium phenylethyl barbiturate (Phenobarbital ${ }^{\circledR}$ ), $15 \mathrm{mg}$

Sodium allylisobutyl barbiturate (Sandoptal ${ }^{\circledR}$ ), $25 \mathrm{mg}$

Scopolamine hydrochloride, $0.08 \mathrm{mg}$.

Dihydroergotamine methanesulphonate, $016 \mathrm{mg}$

From the above composition it will be seen that none of the ingredients is present in quantities which are usually considered active and its effectiveness is therefore derived from the well-known effect of mutual potentiation and synergism Plexonal is also avallable as "Plexonal Forte," in which each of the five ingredients is present in triple the amount found in ordinary Plexonal.

The formula contains three barbiturates, which deffer in onset of action, duration, and in mode of elimination They belong to the long and intermediate acting group of barbiturates Scopolamine hydrochloride is added because of its parasympatholytic action and because its central sedative effects tend to enhance the barbiturates. Dihydroergotamine is an anti-adrenergic agent and its presence makes possible the reduction of the amount of scopolamine to one-fifth of the usual dose Rothlin has stated that ergotamine has a central sedative effect and that it enhances the effects of barbiturates (1)

"Supplies of Plexonal were made avallable through the courtesy of Messrs Sandoz Pharmaceuticals, Montreal, P.Q

†From the Department of Anaesthesia, University of Saskatchewan College of Medicine and University Hospital, Saskatoon, Saskatchewan

- Present address Division of Anesthesia, University of Illinois Research \& Educational Hospitals, Chicago 12, Illinors, U S A

Can Anaes Soc T, vol 4, no 2, Aprl, 1957 
The effects of Plexonal have been studied by a number of investigators. Kadish (4) comments on the prornpt onset of action of the drug and states that it produces six to eight hours of refreshing sleep. Plexonal has been used widely in the treatment of anx.ety and depressive states and in insomnia $(2,3,4,5,6)$. In these conditions it has proved to be a reliable hypnotic-sedative and all authors agree on the absence of undesirable side effects.

\section{Present Study}

In order to evaluate the usefulness of Plexonal in preoperative night sedation 250 patients were studied They were divided into two groups: Group I (150 patients) received Plexonal the night before operation, Group II (100 patients) was submitted to a double blind study

To obtain the mformation required a worksheet was drawn up Each patient was interviewed by the same investgator Special emphasis was laid on ascertaining the time the patent usually retred and usually fell asleep and the usual time of waking. The patient was also asked about delay in onset of sleep, whether sleep was broken, and what the causes for broken sleep were Each was asked about insomnia or dreams All the patients were checked for possible thyroid disease Weight, age, and sex were noted as well as the fact that some patients were in multiple bed wards and otheis in single rooms An attempt was made to assess the degree of apprehension of each patient for the impending operation.

The double blind study was carred out using placebo tablets which were the exact replica of the original drug The nursing stations taking part in the study were supplied with coded vials of Plexonal and placebo tablets. Nether patient, physıcian, nor nurses were aware whether Plexonal or placebo was being given Effects were recorded in the usual manner The code was broken only after the study had been completed

After a pilot study it was decided to give one tablet for each 50 pounds body werght Further allowance was made for the presence of apprehension and the dosage increased by one tablet

\section{Apprehension}

\section{RESULTS}

Determination of the degree of apprehension is frequently difficult since many patients succeed in suppressing therr true emotions Besides the information obtained from interviewing the patient, the opinions of the attending nurses and doctors were taken into account on various occasions.

TABLE I

APPREHENSION

\begin{tabular}{lcccc}
\hline Category & None & Slight & Severe & Totals \\
\hline Straight Plexonal & 157 & 9 & 2 & 168 \\
Plexonal D B S & 35 & 5 & 1 & 41 \\
Placebo & 32 & 9 & 2 & 43 \\
Totals & 67 & 14 & 3 & 84 \\
\hline
\end{tabular}

$\mathrm{x}^{2}=1604$

Degrees of freedom $=2$

Not significant 
In Study I, 157 patients out of a total of 168 studied (93 per cent) were tree trom apprehension after the administiation of Plexonal. In the double blind study, 35 out of 41 ( 85 per cent) were free trom apprehension after Plexonal, but 32 out of 43 individuals ( 74 per cent) also expenenced no apprehension following the placebo. The difference between Plexonal and placebo is statistically not significant.

Onset of Sleep

TABLE II

ONSET OF SLEEP

\begin{tabular}{ccccccc}
\hline & \multicolumn{9}{c}{ Minutes } \\
Category & $1-15$ & $16-30$ & $31-45$ & $46-60$ & $61-90$ & Totals \\
\hline Plexonal D B S & 0 & 18 & 6 & 15 & 5 & 44 \\
Placebo & 1 & 14 & 11 & 18 & 3 & 47 \\
Totals & 1 & 32 & 17 & 33 & 8 & 91 \\
\hline$x^{2}=3652$ & Degrees of freedom $=4$ & \multicolumn{3}{c}{ Not significant }
\end{tabular}

No significant statistical difference exists between Plexonal and the placebo with regard to the onset of sleep

Length of Sleep

TABLE III

A NORMAL SLEEP LENG TH

SLEEP LENGTH

\begin{tabular}{|c|c|c|c|c|c|c|c|c|c|c|c|c|c|c|c|}
\hline \multirow[b]{2}{*}{ Category } & \multicolumn{15}{|c|}{ Hours } \\
\hline & $2 \frac{1}{2}$ & 3 & 4 & $5^{1} 2$ & 6 & $61 / 2$ & 7 & $7^{11 / 2}$ & 8 & $81 / 2$ & 9 & $91 / 2$ & 10 & $101 / 2$ & Totals \\
\hline Plexonal D B S & 1 & 1 & 1 & 1 & 4 & 3 & 3 & 6 & 11 & 4 & 6 & 2 & 2 & 1 & 46 \\
\hline $\begin{array}{l}\text { Placebo } \\
\text { Totals }\end{array}$ & $\begin{array}{l}0 \\
1\end{array}$ & 0 & 0 & 0 & 1 & 1 & 7 & 9 & 5 & 10 & 9 & 4 & 6 & 2 & 54 \\
\hline To & 1 & 1 & 1 & 1 & 5 & 4 & 10 & 15 & 16 & 14 & 15 & 6 & 8 & 3 & 100 \\
\hline
\end{tabular}

B SLEEP LENGTH AF TEK DRULS

\begin{tabular}{|c|c|c|c|c|c|c|c|c|c|c|c|c|}
\hline \multirow[b]{2}{*}{ Categors } & \multicolumn{10}{|c|}{ Hours } & \multirow[b]{2}{*}{9} & \multirow[b]{2}{*}{ Totals } \\
\hline & $31 / 2$ & 4 & 5 & $51 / 2$ & 6 & $61 / 2$ & 7 & $71 / 2$ & 8 & $81 / 2$ & & \\
\hline $\begin{array}{l}\text { Plexonal D B S } \\
\text { Placebo } \\
\text { Totals }\end{array}$ & $\begin{array}{l}1 \\
0 \\
1\end{array}$ & $\begin{array}{l}1 \\
1 \\
2\end{array}$ & $\begin{array}{l}0 \\
2 \\
2\end{array}$ & $\begin{array}{l}0 \\
2 \\
2\end{array}$ & $\begin{array}{l}3 \\
3 \\
6\end{array}$ & $\begin{array}{r}6 \\
4 \\
10\end{array}$ & $\begin{array}{r}14 \\
9 \\
23\end{array}$ & $\begin{array}{r}8 \\
9 \\
17\end{array}$ & $\begin{array}{r}7 \\
14 \\
21\end{array}$ & $\begin{array}{r}2 \\
8 \\
10\end{array}$ & $\begin{array}{l}4 \\
2 \\
6\end{array}$ & $\begin{array}{r}46 \\
54 \\
100\end{array}$ \\
\hline
\end{tabular}

There is no significant difference in the usual length of sleep between the individuals who were to receive Plexonal and those who were to receive the placebo Similarly after administration of the drug the difference between the two groups is statistically not significant

\section{Dreams}

Patients who dream, particularly those who dream frequently or vividly, are usually under some degree of tension and therefore sleep may be relatively light Therefore, a patient who has no dreams, but who usually does dream, might be said to be well sedated 
TABLE IV

1 BEFORH PLEXONAL DREAMS

\begin{tabular}{ccccc}
\hline Category & None & Present & Vivid & Totals \\
\hline Plexonal D B S & 15 & 26 & 5 & 46 \\
Placebo & 16 & 31 & 7 & 54 \\
Totals & 31 & 57 & 12 & 100 \\
\hline Degrees of freedom $=3$ & Not significant &
\end{tabular}

IS AFTER PLEXONAL,

\begin{tabular}{lcccc} 
Category & None & Present & Vivid & Totals \\
\hline Straight Plexonal & 156 & 23 & 2 & 191 \\
Plexonal D B S & 38 & 6 & 1 & 45 \\
Placebo & 39 & 11 & 3 & 53 \\
Totals & 77 & 17 & 4 & 98 \\
\hline $\mathrm{x}^{2}=1$ & Degrees of friedom $=2$ & Not significant
\end{tabular}

There is no statistical significance between the usual dream pattern of the patients who later were to receive either Plexonal or the placebo.

After the administration of Plexonal in Group I the great majority of patients were free from dreams. The same apphed to those undergoing the Double Blind Study and again the difference between Plexonal and the placebo is statistically not significant

\section{Patient's Opinion}

TABLE

PATIENT'S Opinion

\begin{tabular}{lcccc}
\hline Category & Less good & Normal & Better & Totals \\
\hline Straight Plexonal & 9 & 46 & 36 & 91 \\
Plexonal D B S & 6 & 25 & 15 & 46 \\
Placebo & 15 & 31 & 4 & 50 \\
Totals & 21 & 56 & 19 & 96 \\
\hline
\end{tabular}

$\mathrm{x}^{2}=1072 \quad$ Degrees of freedom $=2 \quad$ Highly significant

The vast majority of patients receiving Plexonal in Study I thought that they slept as well as usual or better In the Double Blind Study a similar result was obtained with individuals receiving Plexonal, whereas for those receiving the placebo the relationship was reversed, a relatively large number thought they did not sleep as well after the placebo and only 4 out of 50 thought they slept better Here the difference between Plexonal and the placebo is highly significant

\section{Nurses' Opinion}

It is notorious in hospital practice that the patients' and the nurses' opinion legarding duration and depth of sleep do not concide The nurses thought that of those ieceiving Plexonal in Group I the large majority slept well. In the 
TABLE VI

NURSES' OPINION

\begin{tabular}{lcccc}
\hline Category & Poor & Fair & Good & Totals \\
\hline Straight Plexonal & 4 & 8 & 62 & 74 \\
Plexonal D B S & 2 & 4 & 29 & 35 \\
Placebo & 4 & 5 & 21 & 30 \\
Totals & 6 & 9 & 50 & 65 \\
\hline
\end{tabular}

$x^{2}=1682 \quad$ Degrees of freedom $=2 \quad$ Not significant

Double Blind Study the same opmion was expressed irlespectuve of whether Plexonal or the placebo had been administered The difference is statistically not significant.

\section{Hangover}

The presence of hangover in the morning is indicative of the continumg effect of a drug The large majonty of patients receiving Plexonal in Study I had no

IABLE VII

HANGOVER

\begin{tabular}{lccccc}
\hline Category & None & Slight & Severe & Headache & Totals \\
\hline Straight Plexonal & 149 & 9 & 9 & 7 & 174 \\
Plexonal D B S & 28 & 4 & 8 & 3 & 43 \\
Placebo & 43 & 6 & 0 & 2 & 51 \\
Totals & 71 & 10 & 8 & 5 & 94 \\
$\mathrm{x}^{2}=11$ 186 & Degrees of freedom $=3$ & Significant but not highly significant \\
(dubious)
\end{tabular}

hangover In the Double Blind Study mose patients had no hangover after the placebo than after Plexonal The difference in the two groups is significant from a statistical point of view but not highly so The statistician considered ths difference a rather dubıous one

Results were not significantly affected by age and sex of patients, or by whether the patients were in single rooms, or in double or four-patient wards

\section{Discussion}

If one considered the results of the straight Plexonal study (Study I) by themselves, one would have to conclude that this is indeed a very excellent agent for night sedation and is admirably suted as such to provide sleep and allay apprehension the night before operation The figures obtamed by themselves for Plexonal are most impressive

However, if the figures obtamed in the Double Blind Study ane analysed, one finds to one's surprise that almost equally excellent results are obtained with the placebo Indeed, this conclusion applies to all the factors investigated with the exception of the patient's own opinıon It seems that the patients themselves felt the absence of the sedative effect of the drug more correctly than any tests applied Still the fact remains that even in this gioup the large majority, 25 ont 
of 46 patients, thought they slept no better than they did without sedation (54 per cent) which detracts somewhat from the value of the drug.

This does not mean that Plexonal in itselt is not a useful agent. Rather it seems to imply that a majority of patients in our study did not require sedation the night before operation and that those who did require it needed an agent more potent than Plexonal. Moreover this study clearly re-emphasizes the great importance of the Double Blind Study when evaluatung drugs of this kind $(7,8)$, since without it one would of necessity have concluded that this particular agent was excellent for preoperative night sedation

\section{SUMMARY}

The effectiveness of Plexonal for pı eoperative night sedation has been tested in 250 patients, 100 of whom underwent a Double Blind Study

The fallacy of relying on a stranght study in the evaluation of these drugs has been demonstrated and the necessity of contiolling results with a Double Blind Study has been emphasized. In the last resort it is the patient's subjective response to hypnotic medication which is of prime importance In this respect Plexonal produced a mild but definite soporific effect

\section{RÉSUMÉ}

Nous avons étudié chez 250 malades l'efficacité du Plexonal comme sédatif la veille de l'opération, chez 100 de ces malades, nous avons fait cette étude en employant la technique aveugle, c'est-à-dure en employant des ampoules numérotées dont on ignore le contenu. $S_{1}$ l'on tuent compte des résultats obtenus au cours de l'étude ordınarre du Plexonal, on en vient à la conclusion que ce médicament est excellent comme sédatuf la vellle de l'opération Toutefois, en évaluant les résultats obtenus avec la technique aveugle, on se rend compte que le placebo a donné des résultats d'aussı bonne qualité Dans cette conclusion, nous tenons compte de tous les facteurs étudiés à l'exception de l'opinion personnelle du malade

Cela ne veut pas dıre que le Plexonal n'est pas un médicament utle. Au contraire, ll faudrait croire que la majorité des malades étudiés n'avaient pas besom d'un médıcament ou en avâient besoin d'un plus pussant que le Plexonal. Les résultats obtenus plaident fortement en faveur d'une étude' à technique aveugle quand quelqu'un veut étudier un médicament, car, sạns cette technique, nous en serions venus à conclure nécessaurement que le médicament en question était un excellent sédatif à employer la velle de l'opération

\section{REFERENCES}

1 Rothlin, E The Pharmacology of the Natural and Dihydrogenated Alkaloids of Ergot Bull schweiz. Akad d med Wissensch, 2 249-73 (1947)

2 Kral, V A \& Krauser, W. G Psychiatric Expenences with Plexonal Canad M A I, $70 \quad 453-5$ (Aprl 1954).

3 Simms, L M Plexonal in Treatment of Anxiety and Insomna Dis Nerv System, 16(2) 54-6 (Feb 1955)

4 Kadish, A H Plexonal A New Hypnotic and Sedative Clin Med, 2(4) 379-80 (March 1955 ) 
5. Bankoff, M. L, Kohrman, B M \& Hoover A W Plexonal. A New Hypnotic-Sedative in Office Treatment of Depressive States J Indiana M A, 48(6) 608-11 (June 1955).

6 BLock, C The Evaluation of a New Sedative-Hypnotic J. M Soc New Jersey, 52 363-5 (July 1955)

7 BeEcmer, H K Experimental Pharmacology and Measurement of the Subjective Response Science, 116(3007) 157-62 (August 15, 1952)

8 Lasagna, L A Comparison of Hypnotic Agents J Pharmacol \& Exper Therap, 111(1) 9-20 (May 1954) 